\title{
Menstrual Suppression in Gender Minority Youth
}

\author{
(1) Sinem Akgül11, (1) Zeynep Tüzün11, (1) Melis Pehlivantürk Kızılkan11, (1) Zeynep Alev Özön² \\ ${ }_{1}^{1}$ hacettepe University Faculty of Medicine, Department of Pediatrics, Division of Adolescent Medicine, Ankara, Turkey \\ ${ }^{2}$ Hacettepe University Faculty of Medicine, Department of Pediatrics, Division of Pediatric Endocrinology, Ankara, Turkey
}

\begin{abstract}
What is already known on this topic?
Menstrual distress is frequently reported in gender minority youth (GMY) in sex assigned-at-birth female adolescents identifying as male or gender non-conforming. Menstrual suppression refers to the practice of using hormonal management to reduce menstrual bleeding which may be an option to treat menstrual dysphoria in GMY.
\end{abstract}

\section{What this study adds?}

Menstrual suppression should be offered to GMY when pubertal suppression is not an option. Each treatment plan should be individualized.

\begin{abstract}
The purpose of this case series was to evaluate menstrual suppression in sex assigned at birth female adolescents identifying as male or gender non-conforming. A retrospective chart review of four gender minority youth (GMY), age 14-17, was performed for gender identity history, type and success of menstrual suppression, method satisfaction, side effects and improvement in menstrual distress. Menstrual suppression was successful in three patients, one patient discontinued use due to side effects that caused an increase in gender dysphoria. Menstrual distress and bleeding pattern improved in the majority of GMY in this series but side effects, as well as contraindications, may limit their use. In conclusion, menstrual dysphoria can be life-threatening for GMY and it is important that clinicians consider menstrual suppression in GMY with menstrual dysphoria. This series emphasizes the importance of individualized treatment plans.
\end{abstract}

Keywords: Gender minority youth, menstrual suppression, menstural dysphoria

\section{Introduction}

At our pediatric hospital in Ankara, Turkey, visibility of trans gender youth is growing and we are receiving more applications and referrals of young people whose gender identity does not align with their sex assigned at birth (SAB) more frequently than ever before (1). Gender minority youth (GMY) is an umbrella term that is used to describe this community (2) and gender dysphoria is the term used to describe the stress experienced by these young people (3).

For SAB female adolescents who identify as male or gender non-conforming, puberty and the development of unwanted sex characteristics can be associated with significant psychological stress and may be the trigger for gender dysphoria (4). Menarche can be particularly distressing, as the initiation of menstruation represents a social category of gender to which the person does not belong, and which may lead to stress, anxiety, and dysphoria $(5,6)$.

Menstrual dysphoria is defined as a sense of distress or anxiety associated with menses (7). Menstruation is a monthly reminder to these teens that their SAB does not align with their gender identity. Studies have reported increased rates of depression, thoughts of self-harm and suicidal ideation in GMY while menstruating (8).
Address for Correspondence: Sinem Akgül MD, Hacettepe University Faculty of Medicine,

Department of Pediatrics, Division of Adolescent Medicine, Ankara, Turkey

Phone: +90312305 1160 E-mail: sinemhusnu@gmail.com ORCID: orcid.org/0000-0001-8203-2337

Presented in: This case series was presented as a short oral presentation at the XXIV ${ }^{\text {th }}$ National Pediatric

Endocrinology and Diabetes Congress (30 $0^{\text {th }}$ October- $1^{\text {st }}$ November 2020).

${ }^{\circ}$ Copyright 2022 by Turkish Society for Pediatric Endocrinology and Diabetes

The Journal of Clinical Research in Pediatric Endocrinology published by Galenos Publishing House.
Conflict of interest: None declared Received: 30.11 .2020 Accepted: 19.05.2021 
The first approach to an adolescent with gender dysphoria is confirmation of the diagnosis and continuous follow-up by a mental health professional. The social transition process then continues with the adoption of a new name, and style of dressing congruent with their gender identity, while therapy may include the reversible phase of treatment such as the suppression of puberty with gonadotropin-releasing hormone (GnRH) analogues (4,9). Pubertal suppression has been shown to have a positive effect on psychological function, improve well-being, and alleviate menstrual dysphoria since it provides therapeutic amenorrhea $(10,11)$.

Pubertal suppression should be offered to adolescents experiencing gender dysphoria, but many GMY still struggle to access this treatment (4). Gender affirmative care, especially in the adolescent population, is still developing in Turkey which means the main barrier to treatment is lack of experienced medical providers (1). Furthermore, failure to secure parental consent is another major obstacle to treatment. Even when the patient finds an experienced provider and has parental consent, obtaining the medication may take some time due to the gender informed mental health assessment not yet being completed or the formalities associated with prescribing this treatment.

Provisional therapy to suppress menstruation in GMY with menstrual dysphoria may be used for a number of reasons, including those who do not have the option of pubertal blockers or as an interim approach pending completion of evaluation or until official approval for use of pubertal blockers (7). Menstrual suppression refers to the practice of using hormonal management to reduce menstrual bleeding with the goal of achieving therapeutic amenorrhea (12). The hormonal methods used to manipulate menstruation are totally reversible and studies have shown they may increase quality of life and relieve the menstrual dysphoria experienced by GMY (8).

The objective of the current case series was to describe the experiences of GMY after using a hormonal menstrual suppression method of their choice for menstrual dysphoria.

\section{Case Report}

A retrospective chart review was performed of all GMY evaluated for the first time during September 2018 and May 2020. The diagnosis of gender dysphoria was made according to DSM-5 criteria (13).

Eligibility for the study required that patients had been seen in the adolescent medicine clinic for at least two visits. A total of nine patients were evaluated for gender dysphoria during this time period, and of these two were SAB males who identified as trans female. Menstrual suppression was offered to the remaining seven SAB female patients. Parental consent for menstrual suppression was not obtained in two and one patient was started on a GnRH analog soon after the first evaluation. Thus, a total of four patients between the ages of 14-17 received this treatment for menstrual dysphoria. All patients had regular menstrual patterns before treatment.

\section{Management of Menstrual Distress}

At our institution, menstrual distress related to gender identity is explored with patients at their initial visits. Menstrual suppression is offered to SAB female GMY who request it, and patients are counseled concerning the following three methods:

i. Combined hormonal contraceptives given continuously

ii. Progestin only contraceptive pill

iii. Intramuscular (IM) depot medroxy progesterone acetate (DMPA)

Method of application (oral vs. IM), possible side effects, contraindications and success rates are discussed. All patients receive counselling concerning the efficacy of treatment and it is explained that suppression of menstrual bleeding is not immediately $100 \%$ effective, and that with many options the possibility of "breakthrough bleeding" still exists although it becomes less frequent with time.

Long acting reversible contraceptives such as hormonal implants and intrauterine devices are not offered to the patients due to the lack of provider experience.

\section{Descriptive Data of the Case-series}

Data concerning gender history including identified gender, current age and age of onset of gender dysphoria, age of menarche, baseline hormonal evaluation, psychiatric diagnosis, disclosure of gender identity to family/friends and social transitioning is shown in Table 1.

Information concerning menstrual suppression, such as reason GnRH was not initiated, method chosen, reason for choice of method, side effects and efficacy of the method, patient satisfaction and treatment duration is shown in Table 2.

All patients and parents gave verbal informed consent for the publication of this case-series.

\section{Discussion}

The majority of research concerning GMY health is related to mental health concerns and the use of gender affirming 
hormonal treatments, whereas little data is available related to menstrual health and dysphoria (14). Menstrual distress related to gender identity is frequently reported in GMY and often has a negative impact on mental health (7). This case series aimed to evaluate menstrual suppression in a group of GMY and, to the best of our knowledge, this is the first report from an adolescent population from Turkey. This case series shows the importance of individualized treatment since although all patients were given the same counseling each individual chose a different path.

Historically it was believed that cyclic menstruation was necessary for health but the concept that it did not have beneficial effects, and that menstruation could be controlled was first raised in the 1960s and many studies and systemic reviews have shown both its efficacy and safety $(15,16)$. Since then, menstrual suppression has been used to manage a number of medical conditions (17). Primarily used to control gynecological problems, such as dysmenorrhea, abnormal uterine bleeding, premenstrual syndrome and endometriosis, it can also be used for patients with medical conditions associated with excessive blood loss which includes patients with bleeding disorders or those receiving chemotherapy or conditions where menstruation causes an exacerbation in symptoms, such as catamenial seizures or migraines. It can also be used for menstrual hygiene related concerns in patients with intellectual or developmental delays (12).

The most commonly used method for menstrual suppression used for other indications are combined hormonal contraceptives which contain both estrogen and progesterone (12). For contraceptive purposes these methods have traditionally been used in a cyclic fashion, with 21 days of hormones, followed by a 7-day hormonefree interval during which withdrawal bleeding occurs. With extended or continuous use, the hormone-free week is taken out, which either reduces or totally eliminates the withdrawal bleeding (18). When giving counseling concerning this method it is important to discuss with the patient that although breakthrough bleeding is common in the initial months the rate of amenorrhea increases with continuous use and has been shown to be about $50 \%$ after the first year of use (19).

Although the combined hormonal formulations continue to be the most popular method for suppressing menstruation for other indications, GMY may want to avoid this method due to the perceived feminizing effects of these hormones

\begin{tabular}{|c|c|c|c|c|c|c|c|c|}
\hline & $\begin{array}{l}\text { Gender } \\
\text { identity of } \\
\text { the patient }\end{array}$ & $\begin{array}{l}\text { Current } \\
\text { age } \\
\text { (years) }\end{array}$ & $\begin{array}{l}\text { Age of onset } \\
\text { of gender } \\
\text { dysphoria } \\
\text { (years) }\end{array}$ & $\begin{array}{l}\text { Age of } \\
\text { menarche } \\
\text { (years) }\end{array}$ & Baseline hormonal evaluation & $\begin{array}{l}\text { Psychiatric } \\
\text { diagnosis }\end{array}$ & $\begin{array}{l}\text { Disclosure of } \\
\text { gender identity } \\
\text { to family/friends }\end{array}$ & $\begin{array}{l}\text { Social } \\
\text { transitioning } \\
\text { process }\end{array}$ \\
\hline Case 1 & Transmale & 16 & 12 & 11.9 & 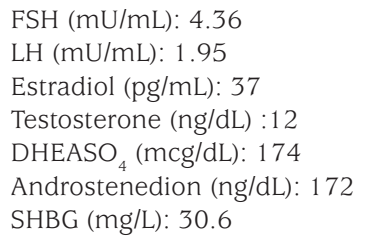 & $\begin{array}{l}\text { Gender } \\
\text { dysphoria } \\
\text { Major } \\
\text { depression }\end{array}$ & Only with family & $\begin{array}{l}\text { Adopted a new } \\
\text { name } \\
\text { Gender } \\
\text { congruent } \\
\text { hair style and } \\
\text { clothing }\end{array}$ \\
\hline Case 2 & Transmale & 14 & 13 & 12.2 & 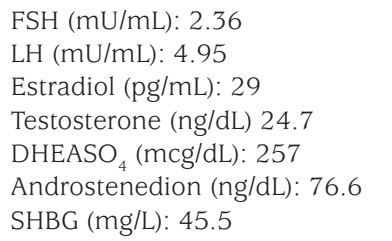 & $\begin{array}{l}\text { Gender } \\
\text { dysphoria } \\
\text { Anorexia } \\
\text { nervosa }\end{array}$ & $\begin{array}{l}\text { Family and } \\
\text { very few closest } \\
\text { friends }\end{array}$ & $\begin{array}{l}\text { Gender } \\
\text { congruent } \\
\text { clothing }\end{array}$ \\
\hline Case 4 & Transmale & 17 & 12 & 12.4 & 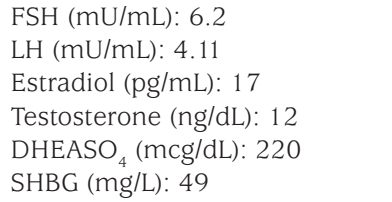 & $\begin{array}{l}\text { Gender } \\
\text { dysphoria }\end{array}$ & Only with family & $\begin{array}{l}\text { Adopted a new } \\
\text { name } \\
\text { Gender } \\
\text { congruent } \\
\text { hair style and } \\
\text { clothing }\end{array}$ \\
\hline
\end{tabular}


and association with an incongruent gender (20), which was the situation for Case 1. It is also important to discuss the possible side effects of the medication, such as its effect on breast tissue. Changes in breast size and/or breast tenderness are known effects of this treatment and these symptoms are made increasingly complicated for those who bind their chests (7). Case 2 discontinued this treatment as the side effects in breast tissue increased his gender dysphoria.

Other methods of choice offered to patients were the progestin only medications, including progestin only pills and the IM DMPA, which are advantageous for GMY as they do not contain estrogen. DMPA is usually administered IM every 12-13 weeks, at a convenient dose schedule of four times per year, which makes it appealing especially to adolescents and the most common bleeding pattern in this method is break through bleeding close to the next injection (21). A modification clinicians can offer to GMY is administering the injection every 10 weeks, which could decrease the break through bleeding when given in shorter cycles. Again, it is important to discuss realistic expectations, as therapeutic amenorrhea may not be achieved straight away and is more likely with continuous use. DMPA is typically associated with amenorrhea in about $50-60 \%$ of users at the end of one year and $70 \%$ by the end of the second year (22). A study by Kanj et al. (6) evaluated menstrual suppression choices among transmale individuals and showed DMPA to be the most common method selected. It is also important to discuss side effects and possible contraindications. The use of DMPA is associated with loss of bone mineral density (BMD) (23). As Case 2 had a history of low BMD, secondary to an eating disorder, use of DMPA was not recommended for this patient. Oral progestin pills were the second choice in Case 3 who continued to have cyclic periods with oral contraceptives. It is important to remember that although progestin only pills may induce amenorrhea they should not be used for patients that additionally require birth control. This patient was not sexually active.

The most common reason for inability to prescribe a GnRH analog in this case series was the time taken to complete mental health evaluation. Our clinic is in a tertiary

\begin{tabular}{|c|c|c|c|c|c|c|c|}
\hline & $\begin{array}{l}\text { Reason GnRH } \\
\text { was not } \\
\text { initiated }\end{array}$ & $\begin{array}{l}\text { Method } \\
\text { chosen }\end{array}$ & $\begin{array}{l}\text { Reason for } \\
\text { choosing this } \\
\text { method }\end{array}$ & $\begin{array}{l}\text { Observed side } \\
\text { effects }\end{array}$ & $\begin{array}{l}\text { Efficacy of the } \\
\text { method }\end{array}$ & $\begin{array}{l}\text { Patient } \\
\text { satisfaction }\end{array}$ & $\begin{array}{l}\text { Treatment } \\
\text { duration }\end{array}$ \\
\hline Case 1 & $\begin{array}{l}\text { Needed time to } \\
\text { complete mental } \\
\text { health evaluation }\end{array}$ & DMPA & $\begin{array}{l}\text { 1. Did not want } \\
\text { to use a method } \\
\text { containing } \\
\text { estrogen } \\
\text { 2. Did not want } \\
\text { to take daily } \\
\text { medication }\end{array}$ & None & $\begin{array}{l}\text { DMPA was initiated } \\
3 \text { times every } 10 \\
\text { weeks. Bleeding } \\
\text { occurred a few days } \\
\text { before each injection }\end{array}$ & High & $\begin{array}{l}\text { DMPA was stopped } \\
\text { after } 1 \text { year as a } \\
\text { GnRH analog was } \\
\text { started }\end{array}$ \\
\hline Case 2 & $\begin{array}{l}\text { Needed time to } \\
\text { complete mental } \\
\text { health evaluation }\end{array}$ & $\begin{array}{l}\text { COC given } \\
\text { continuously }\end{array}$ & $\begin{array}{l}\text { DMPA was } \\
\text { contraindicated } \\
\text { in this patient } \\
\text { due to very low } \\
\text { Bone mineral } \\
\text { density }\end{array}$ & $\begin{array}{l}\text { Breast } \\
\text { enlargement } \\
\text { and increased } \\
\text { breast sensitivity }\end{array}$ & $\begin{array}{l}\text { Only used the } \\
\text { treatment for a } \\
\text { month }\end{array}$ & $\begin{array}{l}\text { Low } \\
\text { Due to the } \\
\text { breast changes } \\
\text { the patient } \\
\text { decided to } \\
\text { discontinue } \\
\text { treatment. }\end{array}$ & $\begin{array}{l}\text { Was started on a } \\
\text { GnRH analog }\end{array}$ \\
\hline Case 3 & $\begin{array}{l}\text { Lack of parental } \\
\text { consent }\end{array}$ & $\begin{array}{l}\text { 1. COC given } \\
\text { continuously } \\
\text { 2. POC }\end{array}$ & $\begin{array}{l}\text { Was scared of } \\
\text { receiving an } \\
\text { injection }\end{array}$ & $\begin{array}{l}\text { Patient } \\
\text { continued to } \\
\text { have cyclic } \\
\text { bleeding on } \\
\text { COC and was } \\
\text { switched to a } \\
\text { POC }\end{array}$ & $\begin{array}{l}\text { Low with COC, } \\
\text { achieved therapeutic } \\
\text { amenorrhea with } \\
\text { POC. Had one break } \\
\text { through bleed on } \\
\text { POC. }\end{array}$ & $\begin{array}{l}\text { Low with COC, } \\
\text { high with POC }\end{array}$ & $\begin{array}{l}\text { Continues to use } \\
\text { POC }\end{array}$ \\
\hline Case 4 & $\begin{array}{l}\text { Lack of parental } \\
\text { consent }\end{array}$ & $\begin{array}{l}\text { 1. COC } \\
\text { 2. DMPA }\end{array}$ & $\begin{array}{l}\text { Was started on } \\
\text { COC as they were } \\
\text { scared of daily } \\
\text { injection but they } \\
\text { constantly forgot } \\
\text { to take it, which } \\
\text { lead to break } \\
\text { through bleeding } \\
\text { and was switched } \\
\text { to DMPA }\end{array}$ & None & $\begin{array}{l}\text { COC was not } \\
\text { effective as patient } \\
\text { was non-compliant } \\
\text { DMPA bleed a few } \\
\text { days every } 3 \text { months. }\end{array}$ & $\begin{array}{l}\text { Low on COC } \\
\text { High on DMPA }\end{array}$ & $\begin{array}{l}\text { DMPA was stopped } \\
\text { after } 1 \text { year as a } \\
\text { GnRH analog was } \\
\text { started }\end{array}$ \\
\hline
\end{tabular}


pediatric hospital and one of the very few to provide gender affirmative care in the country. Due to lack of training, health care providers may not have the means to provide pubertal suppression, but menstrual suppression can be prescribed by both pediatricians and pediatric endocrinologists and, in our opinion, should be until the youth is sent to a center where they can receive gender affirmative care. Another common reason for failure to prescribe pubertal suppression is lack of parental consent, as seen in Case 4, but after a year of DMPA and counseling of both the GMY and his parents, they decided to initiate GnRH therapy. Menstrual suppression can act as a bridge to gender affirmative treatment by giving the family time to adjust to this situation.

\section{Conclusion}

In conclusion, the methods utilized for menstrual suppression in this small group of GMY were well tolerated and beneficial. Menstrual dysphoria can be life threatening for GMY and it is important that menstrual suppression should be considered by health care providers caring for these youths. After detailed counseling, concerning different method types and their possible side effects an individualized treatment plan should be made.

\section{Ethics}

Informed Consent: All patients and parents gave verbal informed consent for the publication of this case-series.

Peer-review: Externally peer-reviewed.

\section{Authorship Contributions}

Surgical and Medical Practices: Sinem Akgül, Zeynep Tüzün, Melis Pehlivantürk Kızılkan, Zeynep Alev Özön, Concept: Sinem Akgül, Design: Sinem Akgül, Data Collection or Processing: Sinem Akgül, Zeynep Tüzün, Melis Pehlivantürk Kızılkan, Zeynep Alev Özön, Analysis or Interpretation: Sinem Akgül, Zeynep Tüzün, Melis Pehlivantürk Kızılkan, Zeynep Alev Özön, Literature Search: Sinem Akgül, Writing: Sinem Akgül, Zeynep Tüzün, Melis Pehlivantürk Kızılkan, Zeynep Alev Özön.

Financial Disclosure: The authors declared that this study received no financial support.

\section{References}

1. Apalı ÖC, Baba İ, Bayrakcı F, Değerli D, Erden A, Peker MS, Perk FG, Sipahi İS, Şenoğlu E, Yılmaz S, Zengin NY, Akgül S. Experience of sexual and gender minority youth when accessing health care in Turkey. Int J Adolesc Med Health 2020;33:445-448.

2. Reisner SL, Greytak EA, Parsons JT, Ybarra ML. Gender minority social stress in adolescence: disparities in adolescent bullying and substance use by gender identity. J Sex Res 2015;52:243-256. Epub 2014 Apr 17
3. Levine DA; Committee On Adolescence. Office-based care for lesbian, gay, bisexual, transgender, and questioning youth. Pediatrics 2013;132:297-313.

4. Olson J, Forbes C, Belzer M. Management of the transgender adolescent. Arch Pediatr Adolesc Med 2011;165:171-176.

5. Frank SE. Queering Menstruation: Trans and Non-Binary Identity and Body Politics. Sociological Inquiry 2020;90:371-404.

6. Kanj RV, Conard LAE, Corathers SD, Trotman GE. Hormonal contraceptive choices in a clinic-based series of transgender adolescents and young adults. Int J Transgend 2019;20:413-420.

7. Lowik AJ. 'Just because I don't bleed, doesn't mean I don't go through it”: Expanding knowledge on trans and nonbinary menstruators. Int J Transgend Health 2021;22:113-125.

8. Akgul S, Bonny AE, Ford N, Holland-Hall C, Chelvakumar G. Experiences of Gender Minority Youth With the Intrauterine System. J Adolesc Health 2019;65:32-38. Epub 2019 Jan 26

9. Coleman E, Bockting W, Botzer M, Cohen-Kettenis P, DeCuypere G, Feldman J, Fraser L, Green J, Knudson G, Meyer W, J. Monstrey S, Adler RK, Brown GR, Devor A, H. Ehrbar R, Ettner R, Eyler E, Garofalo R, Karasic DH, Lev AI, Mayer G, Meyer-Bahlburg H, Hall BP, Pfaefflin F, Rachlin K, Robinson B, Schechter LS, Tangpricha V, van Trotsenburg M, Vitale A, Winter S, Whittle S, Wylie KR, Zucker K. Standards of care for the health of transsexual, transgender, and gender-nonconforming people, version 7. Int J Transgend 2012;13:165-232.

10. de Vries AL, McGuire JK, Steensma TD, Wagenaar EC, Doreleijers TA, Cohen-Kettenis PT. Young adult psychological outcome after puberty suppression and gender reassignment. Pediatrics 2014;134:696-704. Epub 2014 Sep 8

11. Shumer DE, Nokoff NJ, Spack NP. Advances in the Care of Transgender Children and Adolescents. Adv Pediatr 2016;63:79-102. Epub 2016 Jun 3

12. Altshuler AL, Hillard PJ. Menstrual suppression for adolescents. Curr Opin Obstet Gynecol 2014;26:323-331.

13. American Psychiatric Association. Diagnostic and Statistical Manual of Mental Disorders (5th ed.) 2013. Available from: https://dsm. psychiatryonline.org/doi/book/10.11 76/appi.books. 9780890425596

14. Costa R, Colizzi M. The effect of cross-sex hormonal treatment on gender dysphoria individuals' mental health: a systematic review. Neuropsychiatr Dis Treat 2016;12:1953-1966.

15. Nappi RE, Kaunitz AM, Bitzer J. Extended regimen combined oral contraception: A review of evolving concepts and acceptance by women and clinicians. Eur J Contracept Reprod Health Care 2016;21:106-115. Epub 2015 Nov 17

16. Edelman A, Micks E, Gallo MF, Jensen JT, Grimes DA. Continuous or extended cycle vs. cyclic use of combined hormonal contraceptives for contraception. Cochrane Database Syst Rev 2014;2014:CD004695.

17. Dapunt O. Experiences with therapeutic amenorrhea. Zentralbl Gynakol 1965;87:896-903.

18. Edelman A. Menstrual nirvana: amenorrhea through the use of continuous oral contraceptives. Curr Womens Health Rep 2002;2:434438.

19. Teichmann A, Apter D, Emerich J, Greven K, Klasa-Mazurkiewicz D, Melis GB, Spaczynski M, Grubb GS, Constantine GD, Spielmann D. Continuous, daily levonorgestrel/ethinyl estradiol vs. 21-day, cyclic levonorgestrel/ethinyl estradiol: efficacy, safety and bleeding in a randomized, open-label trial. Contraception 2009;80:504-511. Epub 2009 Aug 6

20. Krempasky C, Harris M, Abern L, Grimstad F. Contraception across the transmasculine spectrum. Am J Obstet Gynecol 2020;222:134-143. Epub 2019 Aug 5 
21. Kaunitz AM. Long-acting injectable contraception with depot medroxyprogesterone acetate. Am J Obstet Gynecol 994;170:15431549.

22. Schwallie PC, Assenzo JR. Contraceptive use--efficacy study utilizing medroxyprogesterone acetate administered as an intramuscular injection once every 90 days. Fertil Steril 1973;24:331-339.
23. American College of Obstetricians and Gynecologists Committee on Gynecologic Practice. ACOG Committee Opinion No. 415: Depot medroxyprogesterone acetate and bone effects. Obstet Gynecol 2008;112:727-730 